ELORE (ISSN 1456-3010), vol. $13-1 / 2006$.

Julkaisija: Suomen Kansantietouden Tutkijain Seura ry. Taitto: Jukka Talve. [http://cc.joensuu.fi/ loristi/1_06/mak1_06.pdf]

\title{
Producing the past together: GROUP INTERVIEW AND ORAL HISTORY
}

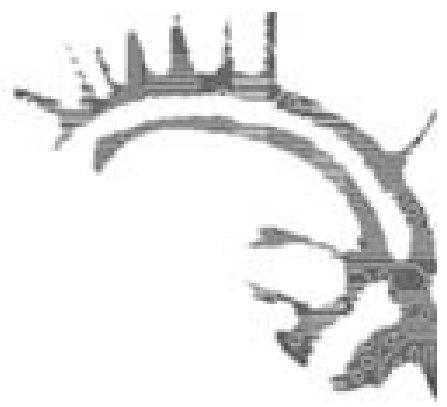

$\underline{\text { Elina Makkonen }}$

Recorded interviews have been the main sources of oral history, and the definitions of oral history emphasize the role of the interview and the orality of the sources (see e.g. Perks \& Thomson 1998, ix; Portelli 1998, 64-66). On the other hand, the written recollections have also been important sources of oral history, for example, in Finland and the Baltic countries (see e.g. Fingerroos 2004; Jaago in this volume; Latvala 2005).

In the research process, an interview can be viewed from different perspectives. In the realist approach, the emphasis is on data collection, and interviews are expected to function as a resource. The social world is assumed to exist independent of language, and the interviewees' accounts are assessed according to how accurately they reflect the real social world. In the idealist approach, in contrast, the recited account is one of the many possible versions or representations of the world. In that position, the interview tends to be treated as a topic rather than a resource and as a social event in its own right. (See e.g. Byrne 2004, 181-183.)

Questions concerning the interview are important in the study of oral history. Oral history and oral accounts have been viewed from various perspectives depending on research questions; they have, for example, been regarded as reconstructions of the past or interpretations of the past (see e.g. Ukkonen 2000, 87). In my research projects, I have concentrated on how oral history is produced, first of all, in the context of an interview and, secondly, in the various oral history projects and publications. For me, the study of oral accounts is not a way of understanding the past as it "really" happened, but a way of seeing how the narratives and oral history are constructed. (1) I am interested in the memories, interpretations and meanings that the narrators carry but also in how the narrators, groups and societies construct their own history.

As an interviewer and a writer of oral history, the researcher is also part of the research process. S/he produces the past together with the narrators. In the field of oral history, the interview is viewed as a co-construction, a dynamic process of interactivity, in which the interviewer takes a major role in shaping the interview 


\section{ELINA MakKonen}

(Perks \& Thompson 1998, 102; cf. Byrne 2004, 181; Morgan 2002, 150). According to Alessandro Portelli, "the documents of oral history are always the result of relationship, of shared project in which both the interviewer and the interviewee are involved together, if not necessary in harmony" (Portelli 1998, 70).

The oral accounts presented during the interviews are constructed in relation to the present. The reminiscence concerns the narrated past (then), but the remembering occurs in the present (now). When the interviewees reminisce their past, they continuously move from the present to the past and vice versa. The past is construed, produced and reshaped in this discursive process. (Knuuttila 1999, 3.)

In an interview situation, the narrators negotiate about their truthful memories and interpretations. Tarja Raninen-Siiskonen points out that the narrators and the researcher make "an agreement on reminiscence". This implicit agreement presupposes that the narrators tell consistent, truthful and meaningful accounts about their past. The narrators and the interviewer are aware of their respective roles. (Raninen-Siiskonen 1999, 362.)

In this article, I will be discussing group interviews. I will concentrate on reminiscence talk and conversations in which the narrators produce the past together with an interviewer and the other narrators. My own fieldwork experiences and interviews are used as examples, but I aim at a wider perspective on oral history interviews and, in particular, on group interviews.

\section{GROUP INTERVIEW AND MY OWN RESEARCH PROJECTS}

More than ten years ago, when I began my first fieldwork project in which I studied people who lived in an industrial community in eastern Finland, I ended up using the group interview as my method. When I tried to find information about the method, I noticed that fieldwork guidebooks and interview and oral history manuals sometimes say something about group interviews (e.g. Goldstein 1974; Grönfors 1982; Hirsjärvi \& Hurme 1988; Ives 1984; Thompson 1988) but sometimes do not mention them at all (e.g. Jackson 1987; Spradley 1979; Suojanen \& Saressalo 1982). Usually, the experts' advice is that one should not use group interviews at all, or at least not as the only method. A conversation with two or more people is regarded as an annoying obstacle that prevents the ethnographer from conducting a "proper" interview (Novojilova 2000).

Earlier, the group interview used to be a fairly uncommon method in folklore studies and cultural anthropology, and the one-to-one interview was used much more. Still, some researchers have studied group situations; for example, Linda Dégh has analysed the roles of narrators in conversational storytelling situations (see e.g. Dégh 1995, 285-305; Dégh \& Vázsonyi 1973). Since the time when I did my first interviews, the situation has changed and group interviews have become more 
common. For instance, in social sciences the focus group interview is a widely accepted method (Morgan 2002, 141). Within the past ten years, the Finnish researchers in folklore studies and social sciences, for example, have used group interviews and group discussions to collect their data (e.g. Saarenheimo 1997; Ukkonen 2000; Vuorinen 2000; Väisänen 2003; see also Valtonen 2005). (2)

The group interviews that I have conducted are connected to three different oral history projects. The first one dealt with childhood in the Kaltimo industrial community at the beginning of the $20^{\text {th }}$ century. (3) In Kaltimo (North Karelia, Eastern Finland), there used to be a cardboard factory, which was opened in 1897 and closed down in 1953. In my research plan, I concentrated, on the one hand, on what the narrators tell about their childhood in the community and, on the other, on how the narrators construe their childhood memories in the context of an interview (Makkonen 1993; 2000). The second project dealt with the local publications of the villages of Kontiolahti, also situated in North Karelia. In that project, me and my colleagues guided working groups (tradition groups) that prepared publications about their own villages. As part of the project, we also conducted group interviews. (4) In addition, I worked as a researcher in the oral history project of the University of Joensuu. That project was mainly based on one-to-one interviews, but there were three group interviews as well. (5)

The projects included groups of different types. First, there were groups in which the narrators were gathered together for an interview. These are called reminiscence groups (cf. Ukkonen 2000, 200); they consist of the factory tradition group and a group of three men, the tradition groups of the Kontiolahti villages, and the groups that discussed the past of the University of Joensuu. Secondly, there are family groups: a married couple and three different groups of sisters (with four, three and two sisters, respectively). All family groups reminisced their childhood in the industrial community. The smallest reminiscence group consisted of three men who recalled their childhood in Kaltimo. The largest groups, on the other hand, consisted of about twenty inhabitants of the Kontiolahti villages; these interviews could also be called community interviews (Slim et al. 1998, 119). Some of the groups gathered together on several occasions (e.g. the group of three men, the factory tradition group and some of the tradition groups of Kontiolahti), but most of them met only once.

The interviews that are used as examples in this article are from the Kaltimo project. The groups include four family groups (three different groups of sisters and a married couple) and two reminiscence groups (a group of three men and the factory tradition group). In addition, my ideas and interpretations are also affected by the different interviewing experiences that I have had in my other projects. The analysed interviews, with the exception of the factory tradition group, are from my own fieldwork. The interviews of the factory tradition group have been collected already in the 1980s, and their interpretation is based tapes that I have listened. 


\section{ELINA MaKKonen}

Anu Valtonen points out that the group interview differs from the focus group. In a group interview situation, the interviewer - in the same way as in a oneto-one interview - asks questions, and each participant answers them. In a focus group, the interviewer is a moderator who brings the topic up for discussion and tries to induce the participants to create a discussion and interact with each other (Valtonen 2005, 223-224; cf. Morgan 2002, 146-147). According to Valtonen's definition, the method I used in my fieldwork was somewhere between a focus group and a group interview. In my interviews, I had a theme list consisting of themes and questions about childhood in the Kaltimo community. There were, however, differences in how I used the list in different situations and how structured or focused the interviews were.

In the different interview situations, my role as a moderator varied. In the first group interviews (1991-1992) with the groups of three men, a married couple and four sisters, I wanted the narrators to discuss the topics on my theme list. Or actually, the first interview with the group of three men was an open interview, but later I used the theme list with this group as well, just as I did with the married couple and the four sisters. These interviews were more focused than the ones that I conducted a few years later. During my first interviews, I was interested in the narrators' childhood memories and had not planned to study the interaction between the members of the group. After having analysed the group interviews of my first fieldwork, I realized that it would be worthwhile to study the actual conversation in the groups: for example, how the interaction between the different participants developed, who was leading the group, what were the roles of the other participants, and how the interpretation about the past was produced together. I changed my research questions and this affected my later interviews. After my first fieldwork project, I was also a little more experienced and encouraged to give more space to the narrators. In the interviews with the groups of three and two sisters (1994; 1996), I let the narrators themselves create the conversation and narrate more freely.

\section{DISCUSSIONS IN THE FAMILY AND REMINISCENCE GROUPS}

The power relations between the different participants could easily be observed in the family groups. It seems that the family members play the same roles in the context of the interview as they do in their everyday life. When I interviewed the married couple, for example, the husband Jaakko tried to act as the leading narrator, since he, presumably, was more dominant in everyday life as well. Although his wife Kerttu was a more important narrator for the purposes of my research project, it was not possible to change the roles in the interview context. It was Jaakko who more often took the role of the narrator, while Kerttu acquiesced in the role of the listener. Still, the roles varied to some extent within the interview. (Cf. Dégh \& Vázsonyi 1973, 100.) 
In the groups of two and three sisters, the roles of everyday life and the hierarchy within the groups were not as evident as in the group of four sisters, in which the eldest sister Alma tried to lead the group and control the other sisters' narratives. Alma interrupted the others' narration and underestimated their opinions and interpretations. The second eldest sister (Eila), on the other hand, was fairly silent and calm but still commented on the other sisters' memories and stories and was critical of her elder sister's interpretations. The third sister (Aune) played the role of a clown. Her narration was quite amusing, and when she spoke the other sisters almost always laughed. The youngest sister (Hilkka) was an onlooker and in most cases just listened to what the others said.

Sometimes, Alma wanted to talk about certain themes that were not under discussion, but I did not allow it. Had I done that, the other sisters would not have had the opportunity to talk about their memories and tell their stories. In general, Alma tended to dominate the discussion, and therefore her memories are the ones most prominently displayed in the material of that group.

In the group of three sisters, the eldest sister (Leena) was a more active narrator than the other two sisters. She also argued more than her sisters. In the group of two sisters, however, it was the younger sister who was more active than the older one. All in all, it seems that the tradition and the recollections are allowed to be dominated and narrated by the eldest of the family, although the others would have something as important to tell (see Goldstein 1974, 62-63).

In the family groups, the narrators told stories and jokes that I did not understood. The narrators also disagreed during the interviews. For example, in the group of two sisters, Helena twice told her sister Sirkka that she should not mumble, because she thought that Sirkka was wrong. The married couple, Kerttu and Jaakko also discussed in quite a normal way - or at least it seemed so. For instance, when the wife was telling about the punishments her mother gave her, her husband got nervous (I never understood why) and commented on her narration quite critically and finally said that she should go and make some coffee. (Cf. Dégh 1995, 290-292.)

The group dynamics and the narrators' behaviour of the reminiscence groups differ from those of the family interviews. In the family interviews, the narrators know each other fairly well or even very well. The hierarchy between the participants has already been established, whereas in the other interviews it will develop during the interview. The beginning of the first interview with the three men is interesting:

- Can we do so that everyone in one's turn tells about where they have lived, or what comes to mind. Then later we can correct those things. Who wants to begin to tell everything that he remembers about his childhood?(Elina)

- Kalle, you can start. (Teuvo)

- Teuvo, I think you can start. I also have quite a lot to tell. I should have written something down. Teuvo, you have to start now. (Kalle) - No, you can start to tell. It seems that Veikko is thinking what he is going to say. (Teuvo) - Yes. I have to recall my memories. (Veikko) 


\section{ELINA MaKKonen}

- At first, where have you lived, each of you? (Elina)

- Veikeko lived in a flat of the factory company. Veikeko, you bave to start, because

you lived in the flat of the company. (Kalle)

- Does the microphone take my voice? (Veikko)

- Yes, it is working. You can speak normally. (Elina)

- Here are Veikeko's views. I was born and lived in the flat of Kankas [factory

company]. (Veikko) (JpaN 39.1996.) (6)

At the beginning of the interview, both Teuvo and Kalle tried to induce one another to start reminiscing. It was Veikko, however, who began after Kalle had encouraged him. Every participant in the group knew each other beforehand. Kalle and Teuvo had participated in the factory tradition group, which had gathered together on several occasions about ten years before I did my fieldwork. Because they had participated in the earlier interviews, they at first tried to inspire each other to talk. The group gathered five times in all, and Veikko was the main narrator. Obviously, the men's personalities and skills as narrators affected their roles in the interview situations.

It is interesting to compare the way the same narrators behaved in different situations. The three sisters were interviewed in a group but also in one-to-one interviews. In the group situation with her sisters, the eldest sister (Leena) stressed how important it was that the children in her family and community learned to work when they were young. Together, Leena and Anna produced an interpretation about a lucky childhood in which work was regarded as a natural and necessary part of ordinary life for everyone who was able to work. Although their mother had been strict, they did not complain about their work and responsibilities.

- Our mother was strict. (Leena)

- Yes she was. (Anna)

- But she, just like our father, guided us to work. If it was your turn to work in the garden (Leena)

- Yes (Anna)

- you had to do everything there. I remember that I had been working in the kitchen and I was in burry. I was going dancing and I had already dressed up. Then mother came and checked with a white napkin whether the stove was clean. It was not, there was some soot there. I had to wash it again. And then we had to polish the copper. And if it was your turn to do the washing, you had to do the ironing and the mangling. In the old days there were ribbons in the pillow cases (Leena)

- those ribbons had to be nice (Anna)

- you had to put them in order with the knife. The roots are there (Leena)

- yes (Anna)

- and I am very thank.ful. We also had time and opportunity for play and games

(Leena)

- yes we had (Anna)

- but you had (Leena)

- yes, everyone had her work and duties (Anna) 
- when we were older (Leena)

- yes, I agree, although (Anna)

- yes, our childhood, I think we had quite a lucky childhood. (Leena)

- Yes. (Anna) JpaN 50.1996.)

However, when Leena was alone, she told me how she protested because her mother demanded too much of her. She recalled how, at school age, she had to do the washing early in the morning. Also in the winter, she had to wash the clothes in the river, as it was done in her childhood. She remembered how much she hated the work:

At that age one should have had something else to do as well, but the work, was the thing. And when I was at school age I had to do the washing. I cried many times because there was so much laundry. (JpaN 54.1996.)

In the one-to-one interview, as opposed to the group interview, the narrator was quite critical towards her family and her work as a child and told how difficult her childhood had been. When one compares these two interviews, it is evident that the context of narrating has influence on the different and even conflicting interpretations of the narrator's past.

The groups in my study differed from one another, and also their ways of interacting and interpreting the past were different. In the factory tradition group, there were more than ten participants, and it took time before the group learned to interact in a disciplined manner. The main aim of the discussion and being together was to construe their own history about the work and life in the industrial community and to build an exhibition. (Heikkinen 1985, 164.) However, the narrators of the family groups and also of the group of three men gathered together because I asked them to. For example, in the group of three men we made an implicit agreement that we would meet a few times and engage ourselves in the project.

The narrators in my fieldwork told about their childhood through certain themes. In the family groups, the narrators had certain roles and hierarchies which affected their interaction also in the interviewing situation. In the groups of sisters, the narrators liked to tell about the themes that were connected with their homes and families. In the group of three men, on the other hand, the recollections and stories were related to the factory, and the work and the environment were more important than in the groups of sisters. Anni Vilkko has pointed out that in the Finnish autobiographies women write more about their homes than men. Women's narration about their homes is connected with both the people and the environment, while men concentrate more on the surroundings outside their homes. (Vilkko 1998, 30, 69.) (7) 


\section{ELINA MAKKONEN}

\section{GROUP INTERVIEW AS AN INTERVIEW METHOD}

It seems that the group interview is a useful method in the oral history projects (see e.g. Heikkinen 1985; Ukkonen 2000). However, if the researcher is interested in life histories, the group interview is not a good method, since it does not bring out individual memories or interpretations as well as a one-to-one interview does (see e.g. Vansina 1985, 62), and the narrators may have less time to provide their personal interpretations and memories in a group. According to Fran Tonkiss (2004, 197-199), focus group research does not seek access to individual opinions or accounts but is concerned with accounts that emerge through interaction, and because of that group interviews can be labelled as interactive discussions.

In a group interview, the narrators stimulate each others' memories and encourage one another to narrate. In a group, the narrators may talk about something they would not even remember in an individual interview (see e.g. Grönfors 1982, 109; Thompson 1988, 120, 205). For example, in the group of three men, one of the narrators said: "Many things came to my mind, when I listened to the boys [the other men in the group] tell about their memories" (JpaN 39.1996).

As a speech event, the group interview is different from a one-to-one interview. The material of the group situation, and also the ways of speaking and discussing, differ from those of one-to-one situations (cf. Saarenheimo 1997, 62, 106). When the narrators are alone with the interviewer, they can concentrate on their personal memories and stories better than in a group. In a one-to-one interview, the narrators usually have longer and more consistent stories than they have in groups. When she was analysing narrating in different situations, Annikki Kaivola-Bregenhøj noticed that in group situations (social occasions) the transition from one motif to another was often very sharp and rapid, and the conversation rambled according to the situation (Kaivola-Bregenhøj 1996, 191; cf. Dégh \& Vázsonyi 1973, 100). In my material, the narrators also told stories in groups, but the comments and accounts of the other participants interrupted these stories. On the other hand, the narrators are able to create stories together, just as the two sisters did at the beginning of their interview:

- That was an event, when we moved to Valliniemi. There was a strong spirit of togetherness, of course, in the neighbourhood there. And we were outsiders and we had to (Sirkka)

- of course, we had to adapt ourselves (Helena)

- adapt ourselves to the society. And I remember, I suppose, we moved there in the summer, or in the autumn (Sirkka)

- it was summer or late summer, because (Helena)

- yes (Sirkka)

- yes, because we had a horse and a cart (Helena)

- yes, and we had (Sirkka)

- we had that cat. (Helena) 


\title{
PRODUCING THE PAST TOGETHER: GROUP INTERVIEW AND ORAL HISTORY
}

\author{
- Yes, we had the cat, whose name was Pörri, and we put her on the top of the load \\ and (Sirkka) \\ - in the bag. (Helena) \\ - in the bag so that she would not go back to our earlier home to Karbunsalo. In the \\ same day, she first went to the wood shed, and stayed there, and then she (Sirkka) \\ - disappeared (Helena) \\ - disappeared. She went back to Karbunsalo. (Sirkka) (JpaN 52.1996.)
}

In a group, the members correct and control one another's narration. If the researcher is aiming for the most truthful interpretation, this is, of course, very important (see e.g. Allen \& Montell 1982, 40; Grönfors 1982, 109; Thompson 1988, 120; Vansina $1985,120)$. In my research project, however, this is not so important, because I am not trying to reconstruct the past. At best, the other members see to it that the themes and topics under discussion are relevant to the interview, but it is still possible that the themes that are important for the researcher are not stimulating to the narrators. In the groups, the narrators and the interviewer constantly negotiate about the relevant, important and interesting topics and themes.

The other member(s) may redirect the narration back to the theme under discussion. In the group of two sisters, Helena, for example, thought that Sirkka changed the subject too early:

- When it started to darken, we went out. It was nice to play everything there in the yard. We played, for example, hide-and-seek. (Sirkka)

- But now you begin to tell about playing games! (Helena)

- No, it is okay to speak about other themes also. (Elina) (JpaN 52.1996.)

The narrators may also help the interviewer by asking questions and encouraging others to talk (cf. Dégh 1995, 289; Portelli 1997, 74-76). When I interviewed the married couple, the wife (Kerttu) repeated my questions to her husband Jaakko:

- As a little boy, I was working in a sawmill, and I was also working (Jaakko)

- Yes. How old were you then? (Elina)

- as a little boy, I worked there, near by the factory (Jaakko)

- How old were you? (Kerttu)

- and I did everything there. (Jaakko)

- How old were you when you started to work in the factory? She is asking, how old you were then. (Kerttu)

- How old? (Jaakko)

- Yes. How old were you when you started to work? (Kerttu)

- It was 1922, or 1921. (Jaakko)

- So, you were ten years old. (Elina) (JpaN 42.1996.)

There are some practical problems concerning the group interviews and the material produced in the groups. I have found out, like Elena Novojilova (2000), that it can be 


\section{ELINA MakKonen}

difficult to record and transcribe group interviews, in particular. If the group includes many participants, it is difficult to record everyone's voice and the whole discussion. In the tradition groups of Kontiolahti, we sometimes used two interviewers and two tape recorders. There were some transcription problems as well. For example, some of the interviews with the sisters were very difficult to transcribe, because the voices were quite similar and it was difficult identify the speaker. Of course, one needs to consider whether one even needs to know who is speaking; after all, the accounts and interpretations are polyphonic and produced together in the context of group conversations (cf. Dégh \& Vázsonyi 1973, 99-100).

Difficulties may also arise if the interviewer has thought of doing a one-toone interview, but there are more people present, such as relatives or neighbours, or additional narrators arrive later and interrupt the interview. The interviewer can either continue the interview with everyone participating in it or stop and try again later (Novojilova 2000). When I was doing my fieldwork with the narrators of the Kaltimo industrial community, I decided to do a few one-to-one interviews, although the majority of the interviews were done in groups. I went to interview a women narrator (Kerttu) who had earlier participated in the factory tradition group. Her husband Jaakko was also at home and then I realized that it was easier to do a group interview. There were some problems in moderating the discussion, and in the actual situation I felt that the interview was not successful, but later, when I listened to it, I found out how interesting it is to analyse the interaction between the wife and the husband. In fact, the interview with the married couple became an important part of my research.

Elena Novojilova (2000) points out that in group situations the interviewer may have difficulties in controlling the events, if $\mathrm{s} / \mathrm{he}$ loses her/his formal role as the one in charge of the situation. Of course it depends on the individual interview how big problem that is. In a structured interview, it is problematic if the interviewer is not able to moderate the group and ask the questions. However, in situations in which the interviewer wants that participants to discuss together, as in focus groups, it is not a problem at all. In a group interview, as in any interview, the interviewer has to concentrate on following the discussion and make sure that it continues and the participants are talking about the themes that are relevant for the study (cf. Morgan 2002, 146-147, 151; Valtonen 2005, 230-231).

I realized that when the narrators are motivated and eager to tell about their life and memories in a group and when they give the other participants the opportunity to talk about their memories and tell their stories, it is quite easy to make an interview and moderate the group. But if the group members do not follow the rules, in other words, if they do not know how to behave in an interview situation, it is difficult to moderate or interview them.

It seems that each group has a member who takes the leading role. If the leader keeps the discussion alive and gives space to the other people's narration, as was the case in the group of three men, it is quite interesting to observe the situation and analyse the way the narrators discuss and produce interpretations together. But if the leader wants to keep on talking and does not give the other members any 
opportunity to speak, which occasionally happened in the group of four sisters, the situation is problematic. At worst, a group interview is a situation full of incoherence and cacophony, and as a result the researcher may end up with material that is very difficult to use.

At best, it is a free and pleasant situation for both the interviewer and the narrators, all of whom have something in common and share their memories and interpretations with the other narrators.

\section{UNIFORM AND MULTI-VOCAL INTERPRETATIONS}

One reason for some researchers to view the group interview as problematic is that in a group people tend to form a uniform interpretation of the topic or theme, instead of providing their personal opinions. It seems that in a group there will be a stronger tendency than in private to produce generalizations about the old days (cf. Thompson 1988, 205). On the other hand, in reminiscence talk about the past communities, there is often a tendency to produce interpretations about the good community spirit (see e.g. Kortelainen 2003). In the discussions of the factory tradition group, the participants produced a joined interpretation of a childhood full of hardships and responsibilities. The narrators evaluated their own childhood by comparing

their lives with the childhood of the present, which they regarded as more carefree:

- Yes, you did not know there was any youth. (Anni)

- You had to take care of the little [children]. (Maila)

- And no child had it like nowadays. They were all working after they were old enough to climb over the doorstep. (Matti)

- I had to do all the housework since I was seven, dishes and washing the floor. (Anni) (JpaN 16.1996.)

The tendency to make exaggerated generalizations in a group interview situation can be seen in the next quotation as well:

A group may subtly pressurise people towards a socially acceptable testimony or a mythical representation of the past or of a current issue which everyone feels is "safe" to share and which may be some sense idealised. Communal histories gathered in this way can involve a powerful process of myth construction or fabulation which misrepresents the real complexity of community. At worst, this can develop into a persistent false consciousness which can only tolerate good things, and remembers "how unite we all were" or which exaggerates the totality of suffering and recalls "how bad everything was". (Slim et al. 1998, 118.) 


\section{ELINA MakKonen}

I agree that in a group the narrators tend to present views that are thought of as socially acceptable; nevertheless, I think this cannot be labelled as fabulation or false consciousness, but rather in a group the narrators are producing the past together and negotiating about their common interpretations. In his fieldwork, Jarno Väisänen noticed that the interviewees of argumentative groups are performing for their community, not only to the other participants in the group. The interviewees knew each other and were aware of the fact that the researcher will use their conversations for his research; because of that, they had to think twice what they can tell in an interview situation. (Väisänen 2003, 278--279.)

Although, a group interview often makes narrations more uniform, it may also bring out different, contradicting and multi-vocal views, if one or some of the members of the group do not accept the interpretation that has been produced together. When the narrators know each other well, as in the group of sisters, they may even argue about their views, stories and memories about the past.

According to David L. Morgan (2002,150-151), focus groups are considered less natural or less valid than individual interviews. I agree with him:

Thus the sense that one kind of interview is more natural than another may be a simple reflection of which of the two is more familiar. From a claim that focus groups are less natural than individual interview it is only a short step to the more serious assertion that they are less valid. According to this argument, people are more likely to say what they "really" think in individual interviews because the presence of other participants during a focus group will influence what everyone says. It certainly is true that the same people might say different things in individual interviews than they would in a group discussion, but that does not mean that one set of statements is distorted and the other is not. Instead, if people say different things in different contexts, that is an interesting fact that may well be worthy of study in its own right. (Morgan 2002, 151.)

I think that questions about validity or authenticity are connected with epistemological questions about interview as part of the research process. If we regard interpretations and oral narratives as something produced in a dynamic process of interactivity in an interview situation, the question about the possible artificiality of the group interview is not relevant at all. However, the situational context in which the oral narratives are told and produced must be considered. (8)

Independent of whether we use a one-to-one interview or a group interview in our oral history projects, we have to pay attention to the questions concerning the context of the interview, the interaction between the narrators as well as the interaction between the narrators and the interviewer. As I have shown in my article, it is interesting - and also important - to study the co-construction and interaction that occurs in an interview situation and to analyze how the interpretations of the past are socially constructed. 


\section{Notes}

1. In Women's Words, Sherna Berger Gluck and Daphne Patai provide useful definitions for the terms oral narratives and oral history. According to them, oral narratives refer to the material gathered in the oral history process (e.g. life history and tape recorded interviews). Oral history, on the other hand, refers to the whole enterprise: recording, transcribing, editing, and making public the resulting product (Gluck \& Patai 1991, 4).

2. There are different types of group interviews and group discussions: e.g. focus groups, group interviews and discussions and joint interviews. In his fieldwork, Jarno Väisänen $(2003,272)$ led argumentative group discussions which included 2-5 participants discussing about the themes the researcher was interested in. In a joint interview, an interviewer and two interviewees are talking together (Arksey 1996). Focus groups may include more than ten interviewees discussing the topic the moderator (interviewer) has determined (Morgan 2002, 141; Valtonen 2005, 223). Focus groups are nowadays used, for example, in social sciences as well as in market and medical research (Gibbs 1997; Morgan 2002; see also Slim et al. 1998, 118.).

3. In my fieldwork about the childhood memories of the Kaltimo industrial community (1992-1993, 1994, 1996), 12 women and 5 men were interviewed about their childhood in the community. The narrators were born between 1910 and the 1940s, and the majority grew up in working class families. In the interviews, I tried to get as much information as possible about their childhood in Kaltimo (e.g. home and family, everyday life and work, school, spare time). The narrators also drew floor plans of their childhood homes and memory maps of their home yards and the factory area.

4. The tradition groups of the Kontiolahti project gathered at the homes and schools of the villages. In the meetings, the participants discussed certain topics (e.g. agriculture, school, co-operative societies and the festivals of the village). The discussions were taped. Later, when the tradition groups were writing and editing their publications, the group interviews were used as data, together with, for example, one-to-one interviews, archive materials, newspaper articles, letters and photographs (see also Makkonen \& Pekkinen \& Raninen-Siiskonen 1999).

5. Interviews about the University of Joensuu were collected in the spring of 2001. At the time, I was working as a researcher in the oral history project of the university. Later I wrote and edited the oral history publication of the university (Makkonen 2004). There were also three students from folklore studies and history working in the project, and the oral history committee guided our work. We interviewed about 100 narrators. They were former and present students and staff of the university (e.g. vice-chancellors, professors, teachers, assistants, researchers, and assisting staff). In the first group interview, four male narrators reminisced about their life as history students in Joensuu in the 1970s. The second group consisted of five people who began to work in the new university in 1969. Their group discussion dealt with the first years of the university. In the third group, two female narrators told about their work in the telephone exchange of the university. 


\section{ELINA MaKkonen}

6. JpaN 52.1996 is an archive sign. The research material is stored in the Joensuu Folklore Archive of the Finnish Literature Society. The names of narrators are changed.

7. About the differences and similarities in the autobiographies of women and men, see e.g. Hyvärinen et al. 1998; Vilkko 1997.

8. About situational context, see e.g. Kaivola-Bregenhøj 1989, 80-8 3.

\section{REFERENCES}

\section{Archival material}

Suomalaisen Kirjallisuuden Seura, Joensuun perinnearkisto (Jpa).

- JpaN 10.-21.1996 (Factory tradition group in 1982-1983)

— JpaN 39.-63.1996 (Elina Makkonen's fieldwork in 1991-1992, 1994, 1996)

\section{Literature}

ALLEN, BARBARA \& MONTELL, WILLIAM LYNWOOD 1982: From Memory to History. Using Oral Sources in Local Historical Research. Nashville, Tennessee: American Association for State and Local History. [1981]

ARKSEY, HILARY 1996: Collecting Data Through Joint Interviews. - Social History Update 15 [online]. < http://www.soc.surrey.ac.uk./sru/SRU15.html > [1.2.2006.]

BYRNE, BRIDGET 2004: Qualitative Interviewing. - Seale, Clive (ed.), Researching Society and Culture. London: Sage. [1998]

DÉGH, LINDA 1995: Narratives in Society: a Performer-Centered Study of Narration. FF Communications 255. Helsinki: Suomalainen Tiedeakatemia, Academia Scientiarum Fennica.

DÉGH, LINDA \& VÁZSONYI, ANDREW 1973: Sägen och tro. - Klintberg, Bengt af (ed.), Tro, sanning, sägen. Tre bidrag till en folkloristisk metodik. Stockholm: PAN/ Norstedts.

FINGERROOS, OUTI 2004: Haudatut muistot. Rituaalisen kuoleman merkitykset Kannaksen muistitiedossa. Suomalaisen Kirjallisuuden Seuran Toimituksia 985. Helsinki: Suomalaisen Kirjallisuuden Seura.

GIBBS, ANITA 1997: Focus Groups. - Social History Update 19 [online]. < http:// www.soc.surrey.ac.uk./sru/SRU19.html > [1.2.2006.]

GLUCK, SHERNA BERGER \& PATAI, DAPHNE 1991: Women's Words. The Feminist Practice of Oral History. New York: Routledge.

GOLDSTEIN, KENNETH S. 1974: A Guide for Field Workers in Folklore. Detroit: Gale. [1964]

GRÖNFORS, MARTTI 1982: Kvalitatiiviset kenttätyömenetelmät. Porvoo: WSOY. 
PRODUCING THE PAST TOGETHER: GROUP INTERVIEW AND ORAL HISTORY

HEIKKINEN, KAIJA 1985: Opettavainen tarina tehdasperinnepiirin toiminnasta. - Kotiseutu 76(3): 163-167.

HIRSJÄRVI, SIRKKA \& HURME, HELENA1988: Teemahaastattelu. Helsinki: Yliopistopaino. [1980]

HYVÄRINEN, MATTI \& PELTONEN, EEVA \& VILKKO, ANNI (eds.) 1998: Liikekwvat erot. Sukupuoli elämäkertatutkimuksessa. Tampere: Vastapaino.

IVES, EDWARD D. 1984: The Tape-Recorded Interview. A Manual for Field Workers in Folklore and Oral History. Knoxville, Tennessee: University of Tennessee Press. [1980] JACKSON, BRUCE 1987: Fieldwork. Urbana, Illinois: University of Illinois Press.

KAIVOLA-BREGENHØJ, ANNIKKI 1989: Factors Influencing the Formulation of Narration. - Siikala, Anna-Leena (ed.), Studies in Oral Narrative. Studia Fennica 33. Helsinki, Suomalaisen Kirjallisuuden Seura.

- 1996: Narrative and Narrating. Variation in Jubo Oksanen's Storytelling. FF Communications No. 261. Helsinki: Suomalainen Tiedeakatemia.

KNUUTTILA, SEPPO 1999: How to Seize Mentalities. - Folklore Fellows' Summer School, Turku 1999. FFSS99, Preprints, 6.

KORTELAINEN, KAISU 2003: Muisteltu Penttilän sahaybteisö. Unpublished licentiate thesis in folklore studies. Joensuu: Joensuun yliopisto, suomen kielen ja kulttuuritieteiden laitos.

LATVALA, PAULIINA 2005: Katse menneisyyteen. Folkloristinen tutkimus suvun muistitiedosta. Suomalaisen Kirjallisuuden Seuran Toimituksia 1024. Helsinki: Suomalaisen Kirjallisuuden Seura.

MAKKONEN, ELINA 1993: Tehtaalaislapsuus muistoissa. Muistitiedon antama kuva elämästä Kaltimon pabvitebtaalla 1910-1940 -luvilla. Unpublished master thesis in folklore studies. Joensuu: Joensuun yliopisto, suomen kielen, kirjallisuuden ja kulttuurintutkimuksen laitos.

— 2000: Elinikäinen lapsuus. Muistikuvia Kaltimon tehdasybteisöstä. Unpublished licentiate thesis in folklore studies. Joensuu: Joensuun yliopisto, suomen kielen ja kulttuuritieteiden laitos.

— 2004: Muistin mukaan. Joensuun yliopiston suullinen historia. Joensuu: Joensuun yliopisto.

MAKKONEN, ELINA \& PEKKINEN, SANNA \& RANINEN-SIISKONEN, TARJA 1999: Kyläkirjaopas. Kultaneito II. Kontiolahti/Joensuu: Suomen Kansantietouden Tutkijain Seura \& Kontiolahden kylien kehittämiskeskusosuuskunta.

MORGAN, DAVID L. 2002: Focus Group Interviewing. - Gubrium, Jaber F. \& Holstein, James A. (eds.), Handbook of Interview Research. Context \& Method. Thousand Oaks: Sage.

NOVOJILOVA, ELENA 2000: Group Interview. Paper presented in International Workshop "Field Methods in Social Sciences" in the European Univeristy of St. Petersburg, Russia 10-12 November 2000.

PERKS, ROBERT \& THOMSON, ALISTAIR 1998 (eds.): The Oral History Reader. London: Routledge.

PORTELLI, ALESSANDRO 1997: The Battle of Valle Giulia: Oral History and the Art of Dialogue. Madison (Wis.): University of Wisconsin Press. 


\section{ELINA MaKKonen}

— 1998: What Makes Oral History Different. - Perks, Robert \& Thomson, Alistair (eds.), The Oral History Reader. London: Routledge.

RANINEN-SIISKONEN, TARJA 1999: Vieraana omalla maalla. Tutkimus karjalaisen siirtoväen muistelukerronnasta. Suomalaisen Kirjallisuuden Seuran Toimituksia 766. Helsinki: Suomalaisen Kirjallisuuden Seura.

SAARENHEIMO, MARJA 1997: Jos etsit kadonnutta aikaa. Vanhuus ja oman elämän muisteleminen. Tampere: Vastapaino.

SLIM, HUGO \& THOMPSON, PAUL \& BENNETT, OLIVIA \& CROSS, NIGEL 1998: Ways of Listening. - Perks, Robert \& Thomson, Alistair (eds.), The Oral History Reader. London: Routledge.

SPRADLEY, JAMES P. 1979: The Ethnographic Interview. New York: Holt, Rinehart and Winston.

SUOJANEN, PÄIVIKKI \& SARESSALO, LASSI (eds.) 1982: Kultturin kenttätutkimus. Tampere: Tampereen yliopisto.

THOMPSON, PAUL 1988: The Voice of the Past. Oral History. Oxford: Oxford University Press.

TONKISS, FRAN 2004: Using Focus Groups. - Seale, Clive (ed.), Researching Society and Culture. London: Sage. [1998]

UKKONEN, TAINA 2000: Menneisyyden tulkinta kertomalla. Muistelupube oman historian ja kokemuskertomusten tuottamisprosessina. Suomalaisen Kirjallisuuden Seuran Toimituksia 797. Helsinki: Suomalaisen Kirjallisuuden Seura.

VALTONEN, ANU 2005: Ryhmäkeskustelut - millainen metodi? - Ruusuvuori, Johanna \& Tiittula, Liisa (eds.), Haastattelu. Tutkimus, tilanteet ja vuorovaikutus. Tampere: Vastapaino.

VANSINA, JAN 1985: Oral Tradition as History. London: Currey.

VILKKO, ANNI 1997: Omaelämäkerta kohtaamispaikkeana. Naisen elämän kerronta ja luenta. Suomalaisen Kirjallisuuden Seuran Toimituksia 663. Helsinki: Suomalaisen Kirjallisuuden Seura.

— 1998: Kodiksi kutsuttu paikka. Tapausanalyysi naisen ja miehen omaelämäkerroista. -Hyvärinen, Matti \& Peltonen, Eeva \& Vilkko, Anni (eds.), Liikekwvat erot. Sukupuoli elämkertatutkimuksessa. Tampere: Vastapaino

VUORINEN, PIHLA 2000: "Entäs muistat sie...” Perbekerronta muisteluna ja merkitysten arviointina. Unpublished master thesis in folklore studies. Joensuu: Joensuun yliopisto, suomen kielen ja kulttuuritieteiden laitos.

VÄISÄNEN, JARNO 2003: Jaettu tieto ja etnografinen aineisto. - Laaksonen, Pekka \& Knuuttila, Seppo \& Piela, Ulla (eds.), Tutkijat kentällä. Kalevalaseuran vuosikirja 82. Helsinki: Suomalaisen Kirjallisuuden Seura.

Phil. lic. Elina Makkonen is a researcher of Folklore in the Department of Finnish and Cultural Research, University of Joensuu. 